\title{
The production and activity in vivo of Proteus mirabilis IgA protease in infections of the urinary tract
}

\author{
B. W. SENIOR, L. M. LOOMES* and M. A. KERR* \\ Departments of Medical Microbiology and " Pathology, Dundee University Medical School, Ninewells Hospital, Dundee \\ DD1 9SY
}

\begin{abstract}
Summary. Immunoblotting of urine from 21 patients of both sexes and of wide age range who had a Proteus mirabilis urinary tract infection (UTI) showed that $14(64 \%)$ specimens contained immunoglobulin A (IgA). In nine (64\%) of these the IgA heavy chain had been degraded to fragments of a size identical to those formed when purified IgA was degraded by pure $P$. mirabilis protease. Urine from patients with clinical evidence of upper UTI contained fragmented IgA and in some of these urine samples $P$. mirabilis protease activity was detectable. Urine infected with a non-proteolytic strain contained only intact IgA. It is concluded that $P$. mirabilis IgA protease is produced and is active during infections of the urinary tract.
\end{abstract}

\section{Introduction}

Proteus mirabilis is a common cause of urinary tract infection (UTI) particularly in young boys ${ }^{1,2}$ and the elderly. ${ }^{3}$ The consequences of this may be serious because $P$. mirabilis has a predilection for the upper urinary tract. ${ }^{4,5}$ The virulence of $P$. mirabilis for the urinary tract arises through the interplay of several factors that include growth rate, ${ }^{6}$ motility, ${ }^{7}$ urease,${ }^{8-12}$ possibly fimbriae, ${ }^{13,14}$ haemolysin ${ }^{15-18}$ and proticines or proticine receptors or both. ${ }^{3}$

Recently we reported that $P$. mirabilis strains of diverse type ${ }^{19}$ and some strains of other Proteus spp. ${ }^{20}$ produce an edetic acid-sensitive protease that cleaves the heavy chain of immunoglobulin A (IgA) outside the hinge region. Subsequently we purified the protease and demonstrated its ability to degrade the heavy chains of both serum and secretory $\operatorname{IgA} A_{1}, \operatorname{Ig} A_{2}$ and IgG isotypes. ${ }^{21}$ Such a broad range of activity against these immunological body defences suggests that the protease may be another important virulence factor of $P$. mirabilis. Therefore, we investigated the production and activity in vivo of $P$. mirabilis protease in patients with UTI.

\section{Materials and methods}

\section{Urine specimens}

Specimens of midstream (MSU) or catheter (CSU) urine were selected at random from those sent for routine bacteriological examination. Only specimens voided and delivered to the laboratory within $2 \mathrm{~h}$, unless refrigerated, were examined. All these contained a pure growth of a Proteus spp. of $\geqslant 10^{5} \mathrm{cfu} / \mathrm{ml}$ for a MSU or an equal or lower count for a CSU. After isolation of the infecting organism, the urine specimens were stored at $-20^{\circ} \mathrm{C}$.

\section{Isolation and identification of bacteria}

The urine was plated on CLED Agar (Oxoid CM 301). After incubation overnight at $37^{\circ} \mathrm{C}$, the infecting Proteus strain was isolated and identified as described previously. ${ }^{22}$

\section{Media}

Casein-CLED agar consisted of CLED agar $36 \mathrm{~g}$ and casein (Sigma) $10 \mathrm{~g}$ in $1 \mathrm{~L}$ of $50 \mathrm{~mm}$ Tris. The casein was dissolved by vigorous stirring and the CLED agar was then added. Gelatin-CLED agar consisted of CLED agar $36 \mathrm{~g}$ and gelatin (Sigma, 300 bloom) $10 \mathrm{~g}$ in $1 \mathrm{~L}$ of $50 \mathrm{~mm}$ Tris. Both media were adjusted to $\mathrm{pH} 8 \cdot 0$, autoclaved at $121^{\circ} \mathrm{C}$ for $15 \mathrm{~min}$ and poured into plates.

\section{Examination for proteolytic activity}

Proteus isolates were inoculated on to the above media. After incubation for $16 \mathrm{~h}$ at $37^{\circ} \mathrm{C}$, the plates were flooded with $1 \mathrm{~N} \mathrm{HCl}$. Caseinase and gelatinase activities were revealed as zones of clearing around the growth of proteolytic strains. 


\section{Preparation and purification of protease}

$P$. mirabilis strain 64676 was grown overnight at $37^{\circ} \mathrm{C}$ on sterile dialysis-tubing membranes placed on Blood Agar (Columbia Agar Base, Oxoid CM 331, supplemented with horse blood $5 \%) .{ }^{19}$ The protease was purified from the washings of the cells and membranes by the method described previously. ${ }^{21}$

\section{Purification of $\operatorname{Ig} A_{1}$}

IgA $A_{1}$ was purified from pooled normal human serum by affinity chromatography of IgA on Jacalin-Sepharose as previously described. ${ }^{21}$

\section{Polyacrylamide gel electrophoresis of urine}

Urine specimens were clarified by centrifugation at $11600 \mathrm{~g}$ for $2 \mathrm{~min}$. The supernate was removed and $50 \mu \mathrm{l}$ was added to $50 \mu \mathrm{l}$ of disruption buffer $(100 \mathrm{mM}$ Tris- $\mathrm{HCl}, \mathrm{pH} 8 \cdot 0$, containing $8 \mathrm{M}$ urea, sodium dodecyl sulphate, SDS, $2 \%$ and a trace of bromophenol blue dye) containing $80 \mathrm{~mm}$ dithiothreitol. The mixture was boiled for $2 \mathrm{~min}$ and $1 \mathrm{M}$ iodoacetamide in disruption buffer was immediately added to the mixture to a final concentration of $100 \mathrm{~mm}$. Protein mol.-wt markers and 60-100- $\mu$ l volumes of the reduced urine samples were loaded on to a stacking gel of polyacrylamide $3 \%$ in $0.125 \mathrm{M}$ Tris $-\mathrm{HCl}, \mathrm{pH} \mathrm{6.8}$, containing SDS $0 \cdot 1 \%$ above a discontinuous separating gradient gel of acrylamide $5-15 \%$ in $0.375 \mathrm{M} \mathrm{Tris}-\mathrm{HCl}$, pH $8 \cdot 9$, containing SDS $0.2 \%$. The upper tank buffer consisted of Tris $0.63 \%$, glycine $0.39 \%$ and SDS $0.1 \%$, $\mathrm{pH} 8.9$, and the lower tank buffer consisted of Tris $1 \cdot 2 \%$ and SDS $0 \cdot 1 \%, \mathrm{pH} 8 \cdot 1$. Electrophoresis was performed at $25 \mathrm{~mA}$ in the cold until the dye front reached the bottom of the gel.

\section{Immunoblotting}

The proteins separated on the polyacrylamide gel were transferred to a nitrocellulose membrane by electrophoresis in methanol $10 \%$ containing $25 \mathrm{~mm}$ Tris and $190 \mathrm{~mm}$ glycine at $4^{\circ} \mathrm{C}$ for $16 \mathrm{~h}$ at $10 \mathrm{~V}$. The membrane was then stained with Ponceau $\mathrm{S}$ dye $0.2 \%$ in trichloroacetic acid $3 \%$ and the position of the mol.wt proteins marked. After washing thoroughly in phosphate-buffered saline (PBS), the membrane was agitated for $2 \mathrm{~h}$ at room temperature in PBS containing dried milk powder (Marvel) $5 \%$ and then washed in several changes of PBS. It was then incubated with agitation in alkaline phosphatase-conjugated goat anti-human $\operatorname{IgA}(\alpha$-chain specific) (Sigma) diluted 1 in 200 in dried milk powder $5 \%$ in PBS containing azide $0.1 \%$ for $2 \mathrm{~h}$ at room temperature. The membrane was then washed for $30 \mathrm{~min}$ in several changes of PBS. The immunoblot was developed in $30 \mathrm{ml}$ of buffer $(100 \mathrm{~mm} \mathrm{NaCl}, 5 \mathrm{~mm} \mathrm{MgCl}$ and $100 \mathrm{~mm}$ Tris- $\mathrm{HCl}$, pH 9.5) containing bromochloroindolyl phosphate (Sigma) $5 \mathrm{mg}$ and nitroblue tetrazolium (Sigma) $10 \mathrm{mg}$.

\section{Detection of protease in urine}

Urine specimens were clarified by centrifugation at $11600 \mathrm{~g}$ for $2 \mathrm{~min}$ and $50 \mu \mathrm{l}$ of the supernate was added to $50 \mu \mathrm{l}$ of sample buffer $(0 \cdot 125 \mathrm{M}$ Tris- $\mathrm{HCl}$, pH 6.8 , containing glycerol $20 \%$, SDS $4 \%$, mercaptoethanol $1 \%$ and a trace of bromophenol blue dye). The mixture was loaded on to a stacking gel of acrylamide $4 \%$ in $0.125 \mathrm{M}$ Tris- $\mathrm{HCl}, \mathrm{pH} 6.8$, buffer containing SDS $0.1 \%$, above a resolving gel of acrylamide $11 \%$ containing gelatin $0 \cdot 1 \%$ in $0.375 \mathrm{M}$ Tris- $\mathrm{HCl}, \mathrm{pH} 8.9$, buffer containing SDS $0.2 \%$. The upper tank buffer was Tris $0.63 \%$, glycine $0.39 \%$, SDS $0.1 \%$, pH 8.9 . The lower tank buffer was Tris $1.2 \%$ and SDS $0.1 \%$, $\mathrm{pH} 8 \cdot 1$. Electrophoresis was performed in the cold at $15 \mathrm{~mA}$ for $16 \mathrm{~h}$.

To remove SDS, the resolving gel was washed twice in $500 \mathrm{ml}$ of Triton X100 $2.5 \%$ in water, each time for $1 \mathrm{~h}$ at $4^{\circ} \mathrm{C}$, and then immersed in $50 \mathrm{~mm}$ Tris- $\mathrm{HCl}$, $\mathrm{pH} 8.0$, buffer and incubated for $4 \mathrm{~h}$ at $37^{\circ} \mathrm{C}$. The gel was subsequently stained in Coomassie Brilliant Blue R $2500 \cdot 125 \%$ in methanol $50 \%$ and acetic acid $10 \%$ for $2 \mathrm{~h}$ and destained overnight in methanol $10 \%$ and acetic acid $10 \%$ in water. The presence and size of protease was indicated by the position of clear areas of unstained degraded gelatin against a blue background of undegraded stained gelatin.

\section{Results}

Twenty-two specimens of urine from 21 patients (10 male, 11 female) aged 4-97 years were examined (table). In each specimen the infecting organism was $P$. mirabilis. All the $P$. mirabilis isolates except strain 29139G were proteolytic and degraded both gelatin and casein.

The results of the immunoblots of 18 of the 22 urine specimens are presented in fig. 1. Purified protease from $P$. mirabilis strain 64676 degraded the $\alpha$ chain of purified $\operatorname{IgA}_{1}(66 \mathrm{Kda})$ (lane 1) to two fragments of 60 and $47 \mathrm{Kda}$ (lane 2). Eight (36\%) urine specimens did not contain detectable IgA. Five $(23 \%)$ urines contained different amounts of intact $\alpha$ chain and nine ( $41 \%$ ) contained $\alpha$ chain that had been degraded to fragments of 60 and $47 \mathrm{Kda}$ or a fragment of $47 \mathrm{Kda}$ only. Specimen $\mathbf{M}$, which was infected with the nonproteolytic strain of $P$. mirabilis, contained a significant amount of intact $\alpha$ chain but not chain fragments.

Electrophoretic analysis of urine on acrylamidegelatin gels showed that four specimens contained active protease indistinguishable in size from that of pure $P$. mirabilis protease (fig. 2 ). These urine specimens were some of those in which $\alpha$ chain fragments were detected.

\section{Discussion}

Secretory IgA in mucous secretions protects mucous membranes from damage by micro-organisms and 
Table. Specimens of $P$. mirabilis-infected urine examined for $\operatorname{IgA}$ and $\operatorname{IgA}$ fragments

\begin{tabular}{|c|c|c|c|c|c|}
\hline \multirow{2}{*}{ Specimen } & \multirow{2}{*}{$\begin{array}{l}\text { P. mirabilis } \\
\text { isolate }\end{array}$} & \multirow{2}{*}{$\begin{array}{l}\text { Type of } \\
\text { specimen }\end{array}$} & \multicolumn{3}{|c|}{ IgA } \\
\hline & & & detected & intact & fragmented \\
\hline A & 02337R & $\mathrm{CSU}$ & + & + & \\
\hline B & 27831K & ND & + & + & \\
\hline $\mathrm{C}$ & $13102 \mathrm{~F}$ & CSU & + & & + \\
\hline D & $32262 R$ & MSU & + & + & \\
\hline$E^{*}$ & $27729 A$ & CSU & + & & + \\
\hline $\mathrm{F}$ & $26071 \mathrm{~V}$ & CSU & + & & + \\
\hline G & $10966 \mathrm{~V}$ & CSU & + & & + \\
\hline $\mathrm{H}$ & $03060 \mathrm{~S}$ & CSU & + & & + \\
\hline I & $32404 B$ & MSU & - & & \\
\hline $\mathbf{J}$ & $17074 G$ & CSU & + & & + \\
\hline $\mathrm{K}$ & $15585 \mathrm{X}$ & MSU & - & & \\
\hline $\mathrm{L}$ & 29878D & CSU & + & & + \\
\hline $\mathbf{M}$ & $29139 \mathrm{G}$ & $\mathrm{CSU}$ & + & + & \\
\hline $\mathbf{N}$ & $29066 \mathrm{~K}$ & CSU & + & & + \\
\hline O & $17410 \mathrm{Y}$ & CSU & - & & \\
\hline $\mathrm{P}$ & $28707 \mathrm{~N}$ & MSU & - & & \\
\hline $\mathrm{O}$ & $32114 \mathrm{~W}$ & ND & + & & + \\
\hline $\mathbf{R}$ & $26927 \mathrm{~W}$ & MSU & - & & \\
\hline $\mathrm{S}^{*}$ & $30691 Y$ & CSU & + & + & \\
\hline$T$ & $30298 \mathrm{G}$ & CSU & - & & \\
\hline $\mathrm{U}$ & $28287 \mathrm{~K}$ & CSU & - & & \\
\hline V & $00030 \mathrm{~F}$ & ND & - & & \\
\hline
\end{tabular}

ND, urine specimen not defined.

* Specimens from same patient.

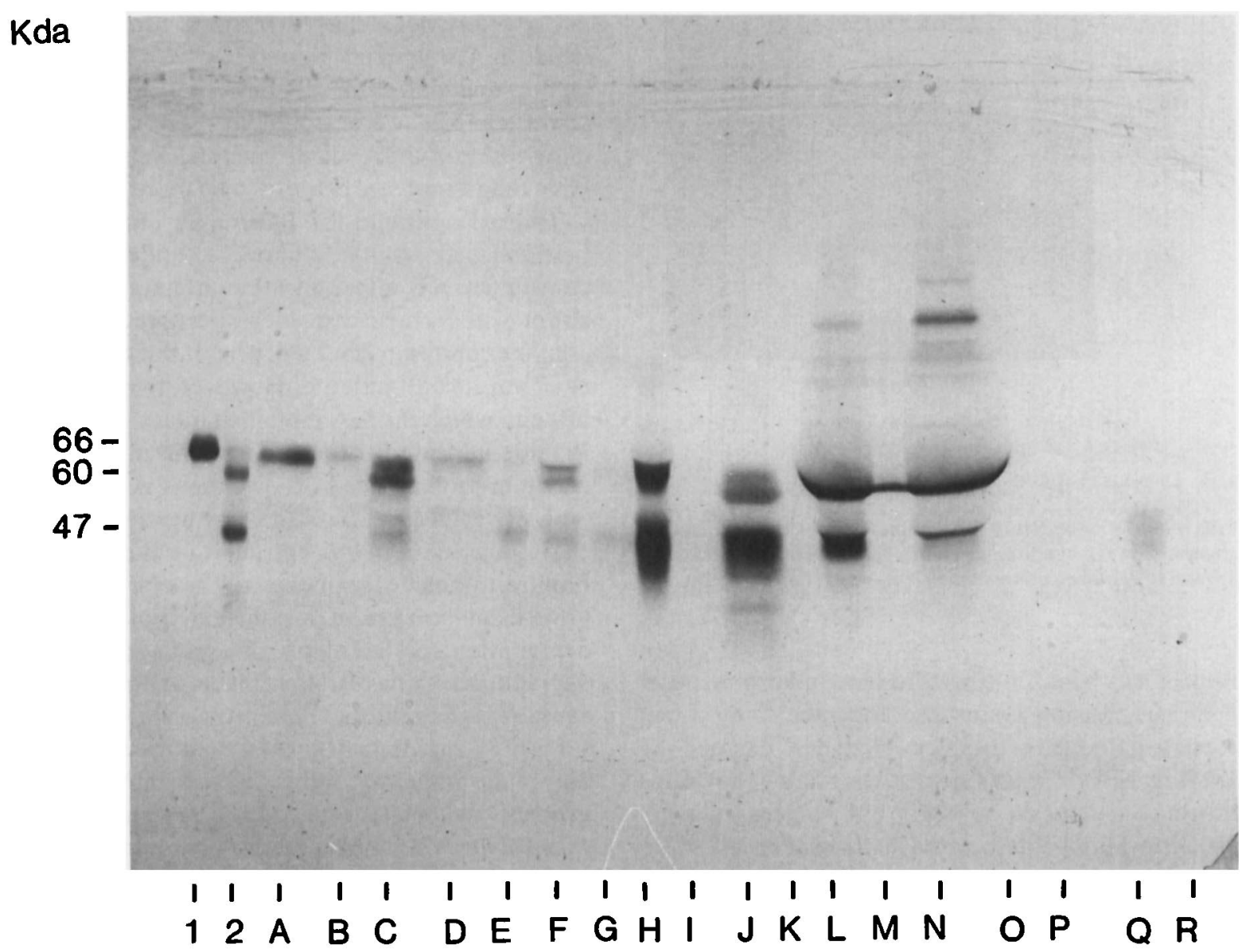

Fig. 1. Immunoblot of electrophoresed $P$. mirabilis-infected urine samples with alkaline phosphatase-conjugated goat anti-human $\alpha$-chainspecific IgA. Lane 1, purified serum IgA 1 ; , purified serum IgA digested with purified $P$. mirabilis strain 64676 protease to fragments of 60 and $47 \mathrm{Kda} ; \mathrm{A}-\mathrm{R}, \boldsymbol{P}$. mirabilis-infected urine specimens. Urine samples $\mathrm{I}, \mathrm{K}, \mathrm{O}, \mathrm{P}$, and $\mathrm{R}$ (and T, U and V not shown) did not contain detectable IgA. Urine samples A, B, D and $M$ (and S not shown) contained different amounts of intact $\alpha$-chain. Urine samples C, F, H, J, L and $N$ contained $\alpha$-chain fragments of 60 and $47 \mathrm{Kda}$ and urine samples $\mathrm{E}, \mathrm{G}$ and $\mathrm{Q}$ an $\alpha$-chain fragment of $47 \mathrm{Kda}$. 


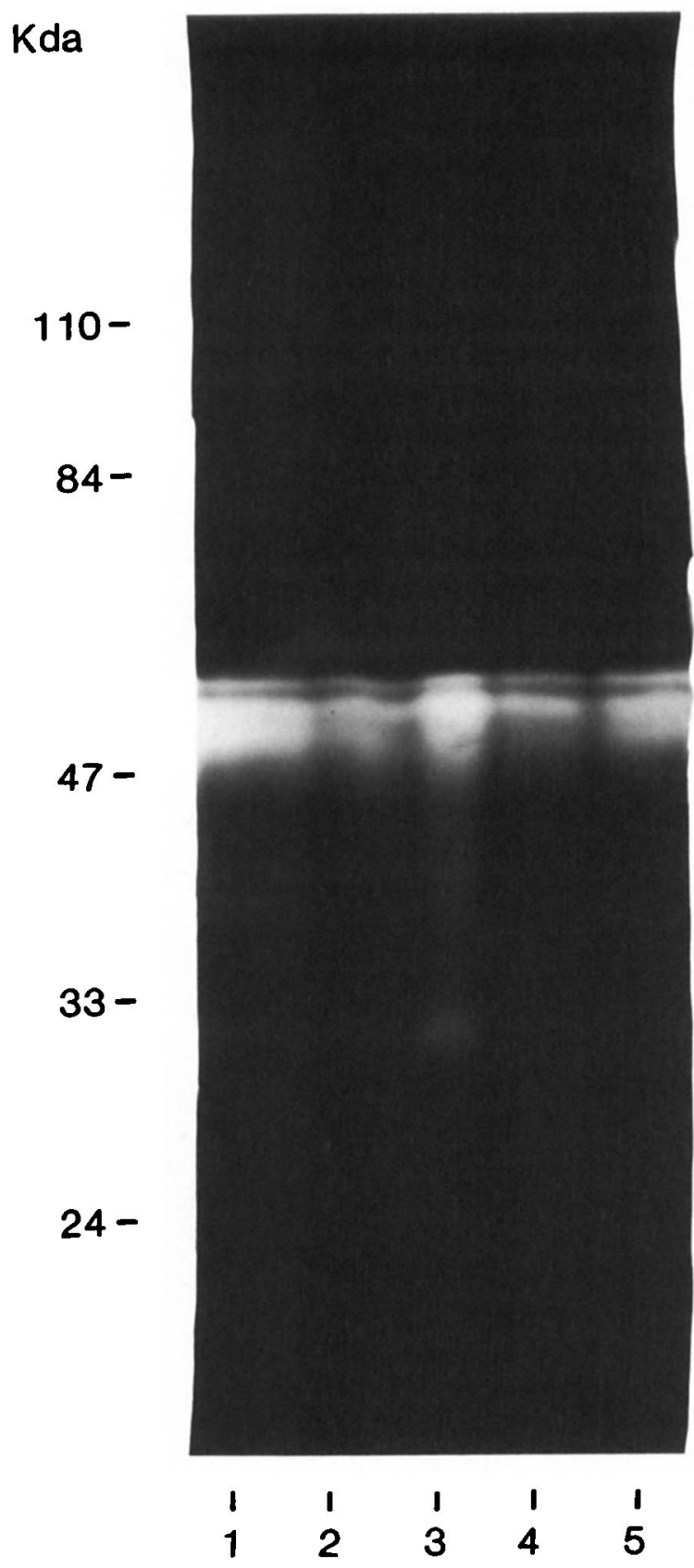

Fig. 2. Demonstration of protease activity in infected urine specimens $\mathrm{H}$ (lane 1), J (2), L (4) and N (5) and purified protease from $P$. mirabilis strain 64676 (3). Samples were electrophoresed on polyacrylamide gels containing gelatin. Numbers on left refer to $M_{r}$ (Kda) and the position of prestained mol.-wt protein markers.

their products by inhibiting adhesion and colonisation and by neutralising toxins and enzymes. Only a few bacterial pathogens produce enzymes capable of degrading $\operatorname{IgA}{ }_{1}{ }^{23}$ and since other related but nonpathogenic species do not form $\operatorname{Ig} \mathrm{A}_{1}$ proteases, their production may be associated with virulence. ${ }^{24}$ The ability of these proteases to function in vivo is suggested by the demonstration of $\alpha$-chain fragments in vaginal secretions from women with gonococcal infection and in cerebrospinal fluid from patients with Haemophilus influenzae meningitis. ${ }^{25}$

The protease of $P$. mirabilis is somewhat different from other IgA $A_{1}$ proteases because its activity is not confined to the $\operatorname{Ig} \mathrm{A}_{1}$ isotype but includes serum and secretory $\operatorname{Ig} \mathrm{A}_{1}, \operatorname{Ig} \mathrm{A}_{2}, \operatorname{IgG}$ and other non-immunoglobulin proteins including secretory component, casein and bovine serum albumin. ${ }^{21}$ Such a wider range of activity is clearly to the advantage of an organism seeking to establish infection.

We have, for the first time, shown here that $64 \%$ of urines from patients with P. mirabilis UTI in which IgA was detectable contained $\alpha$-chain fragments of a size identical to those formed when the $\alpha$-chain is degraded by pure $P$. mirabilis protease. Such fragments were not formed when the infecting strain was nonproteolytic. This is indirect evidence for the production and activity in vivo of $P$. mirabilis protease in UTI. The formation of $\alpha$-chain fragments of 60 and $47 \mathrm{Kda}$ is a feature of low protease activity or early degradation, whereas formation of a single fragment of $47 \mathrm{Kda}$ is a feature of high protease activity or more extensive degradation (unpublished results).

Some of the urine specimens in which $\alpha$-chain fragments were found were also shown by electrophoresis on gelatin-acrylamide gels to contain a protease of the same size as pure $P$. mirabilis protease. This is direct evidence of production in vivo of $P$. mirabilis protease in urine. Electrophoresis on acrylamidegelatin gels is an extremely sensitive method of detecting protease. However, in spite of this, protease activity was not detected in some urine samples in which IgA fragments were found. We believe this to be the result of loss of enzyme activity on storage. The urine samples were stored at $-20^{\circ} \mathrm{C}$ to preserve antibody and antibody fragments. Subsequently we have found protease activity to be more stable at $4^{\circ} \mathrm{C}$.

The $\mathrm{pH}$ optimum for $P$. mirabilis protease is $\mathrm{pH} 8$ (unpublished results). Therefore, under normal circumstances of infection, the infecting $P$. mirabilis strain will form urease, degrade urea and produce alkaline conditions that will permit the protease to act in vivo at its optimal rate. However, five patients had urine in which the IgA remained intact. For specimen $M$, this appeared to be because the infecting strain was non-proteolytic. For specimens A, B, D and S with $\mathrm{pH}$ values of $9,8,9$ and 9 respectively, lack of $\alpha$ chain degradation was not due to unfavourable $\mathrm{pH}$. Failure to detect fragments in these specimens may have been because of insufficient protease to cause degradation, or too short an incubation period for degradation to have taken place. Alternatively, because it is thought that IgA protease activity may be subject in vivo to anti-protease antibody, ${ }^{26}$ the $\operatorname{IgA}$ may have remained intact because antibody to the protease had been formed during a previous UTI with $P$. mirabilis. The latter hypothesis would explain why $\alpha$-chain fragments were not detected in urine specimen $S$, though they had been present during an infection 17 days earlier (specimen E).

All specimens in which degraded IgA fragments were found came from CSU specimens from elderly patients (mean age 72 years) of both sexes with clinical evidence of UTI, although the bacterial count of some 
was only $10^{3}-10^{4} \mathrm{cfu} / \mathrm{ml}$. On the other hand, urines in which $\operatorname{IgA}$ was not detected, were from younger patients (mean age 43 years) for whom clinical evidence of infection, before microbiological confirmation, was generally less clear, and they included four of the five MSU specimens. The significance of

\section{References}

1. Bergström T. Sex differences in childhood urinary tract infection. Arch Dis Child 1972; 47: 227-232.

2. Hallett RJ, Pead L, Maskell R. Urinary infection in boys: a three-year prospective study. Lancet 1976; 2: 1107-1110.

3. Senior BW. The special affinity of particular types of Proteus mirabilis for the urinary tract. $J$ Med Microbiol $1979 ; 12$ : 1 8.

4. Fairley KF, Grounds AD, Carson NE et al. Site of infection in acute urinary tract infection in general practice. Lancet $1971 ; 2: 615-618$.

5. Svanborg Edén C, Larsson $P$, Lomberg $H$. Attachment of Proteus mirabilis to human urinary sediment epithelial cells in vitro is different from that of Escherichia coli. Infect Immun 1980; 27: 804-807.

6. Senior BW. Proteus morgani is less frequently associated with urinary tract infections than Proteus mirabilis - an explanation. J Med Microbiol 1983; 16: 317-322.

7. Pazin GJ, Braude AI. Immobilizing antibodies in urine. II. Prevention of ascending spread of Proteus mirabilis. Invest Urol 1974; 12: 129-133.

8. Senior BW, Bradford NC, Simpson DS. The ureases of Proteus strains in relation to virulence for the urinary tract. $J$ Med Microbiol 1980; 13: 507-512.

9. Braude AI, Siemienski J, Shapiro AP. The role of bacterial urease in the pathogenesis of pyelonephritis. In: Quinn EL, Kass EH (eds) Biology of pyelonephritis. London, Churchill Livingstone. 1960: 69-88.

10. Braude AI, Siemienski J. Role of bacterial urease in experimental pyelonephritis. $J$ Bacteriol $1960 ; 80: 171-179$.

11. MacLaren DM. The significance of urease in Proteus pyelonephritis : a bacteriological study. J Pathol Bacteriol 1968; 96 : 45-56.

12. Musher DM, Griffith DP, Yawn D, Rossen RD. Role of urease in pyelonephritis resulting from urinary tract infection with Proteus. J Infect Dis 1975; 131 : 177-181.

13. Silverblatt FJ. Host-parasite interaction in the rat renal pelvis. A possible role for pili in the pathogenesis of pyelonephritis. $J$ Exp Med 1974; 140: 1696-1711.

14. Silverblatt FJ, Ofek I. Influence of pili on the virulence of these clinical observations must be established to understand more fully the in-vivo role of $\operatorname{IgA}$ protease in UTI.

We acknowledge with gratitude the financial support of the Scottish Home and Health Department.

Proteus mirabilis in experimental hematogenous pyelonephritis. J Infect Dis 1978; 138 : 664-667.

15. Peerbooms PGH, Verweij AMJJ, MacLaren DM. Investigation of the haemolytic activity of Proteus mirabilis strains. Antonie van Leeuwenhoek 1983; 49: 1-11.

16. Peerbooms PGH, Verweij AMJJ, MacLaren DM. Vero cell invasiveness of Proteus mirabilis. Infect Immun 1984; 43: 1068-1071.

17. Senior BW, Hughes C. Production and properties of haemolysins of clinical isolates of the Proteeae. $J$ Med Microbiol $1988 ; 25: 17-25$.

18. Koronakis V, Cross M, Senior B, Koronakis E, Hughes C. The secreted hemolysins of Proteus mirabilis, Proteus vulgaris, and Morganella morganii are genetically related to each other and to the alpha-hemolysin of Escherichia coli. J Bacteriol 1987; 169: 1509-1515.

19. Senior BW, Albrechtsen M, Kerr MA. Proteus mirabilis strains of diverse type have IgA protease activity. J Med Microbiol 1987; 24: 175-180.

20. Senior BW, Albrechtsen M, Kerr MA. A survey of IgA protease production among clinical isolates of Proteeae. $\mathrm{J} \mathrm{Med}$ Microbiol 1988; 25 : 27-31.

21. Loomes LM, Senior BW, Kerr MA. A proteolytic enzyme secreted by Proteus mirabilis degrades immunoglobulins of the immunoglobulin $A_{1}\left(\operatorname{Ig} A_{1}\right), \operatorname{Ig} A_{2}$ and $\operatorname{IgG}$ isotypes. Infect Immun 1990; 58: 1979-1985.

22. Senior BW, Leslie DL. Rare occurrence of Proteus vulgaris in faeces: a reason for its rare association with urinary tract infections. J Med Microbiol 1986; 21 : 139-144.

23. Kilian M, Thomsen B, Petersen TE, Bleeg HS. Occurrence and nature of bacterial IgA proteases. Ann N Y Acad Sci 1983; 409: 612-624.

24. Mulks MH, Plaut AG. IgA protease production as a characteristic distinguishing pathogenic from harmless Neisseriaceae. $N$ Engl J Med 1978; 299: 973-976.

25. Kilian $\mathbf{M}$, Reinholdt J. Interference with IgA defence mechanisms by extracellular bacterial enzymes. In: Easmon CSF, Jeljaszewicz J (eds) Medical microbiology, vol 5. London, Academic Press. 1986: 173-208.

26. Gilbert JV, Plaut AG, Longmaid B, Lamm ME. Inhibition of microbial IgA proteases by human secretory IgA and serum. Mol Immunol 1983; 20: 1039-1049. 